Alexandre Rouette

Université du Québec à Trois-Rivières, Canada

\title{
THE SHORTCOMINGS OF A CONCEPT INERTIA AND CONATUS IN THE PHILOSOPHY OF SPINOZA
}

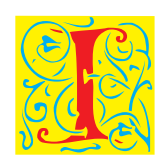

$\mathrm{n}$ the third part of the Ethics, Spinoza express the desire to talk about "human actions and appetites just as if it were a question of lines, planes, and bodies" (E3, Appendix). ${ }^{1}$ With this sentence, it seems clear that Spinoza sides with Hobbes and Descartes and that he wants to construct a mechanistic theory of the affects. In the same part of the Ethics, Spinoza also introduces the concept of conatus: "Each thing, as far as it can by its own power, strives to persevere in its being" (E3P6), Spinoza says. One will immediately understand this concept of conatus as the core concept of his mechanistic theory of the affects, the concept without which this mechanistic account of the affects would be impossible.

However, in the second part of the Ethics, there is another concept that could have accomplished that same goal, namely, the principle of inertia. In the words of Spinoza, "A body which moves or is at rest must be determined to motion or rest by another body, which has also been determined to motion or rest by another, and that again by another, and so on, to infinity" (E2L3). Interestingly enough, in the philosophy of Hobbes, the concept of endeavour/conatus is much nearer to the Spinozistic principle of inertia in its meaning than it is to the Spinozistic version of the conatus. However, Hobbes is still able to construct a deeply mechanistic theory of the affects with this concept, and one may think that Spinoza should have been too.

In this paper, I aim to address the question of why Spinoza has decided to use the concept of conatus rather than the principle of inertia to achieve his goal of constructing a mechanistic theory of the affects. I will then argue that for this

1 E. Curley, A Spinoza Reader: The Ethics and Other Works, Princeton: Princeton University Press, 1994. For the Ethics, I will use the conventional method of citation. 
purpose, the principle of inertia had serious shortcomings that only the conatus could resolve.

This question will give us insights into the larger problem of the interaction, or absence of one, between the concept of conatus and the principle of inertia. As one should immediately notice, both concepts must be conceived as a kind of principle of conservation: a principle of conservation of the being in the case of the conatus, a principle of conservation of motion in the case of inertia. But, on the one hand, Spinoza introduces the principle of inertia in his physics for never using it again in all of his philosophy while, on the other hand, the conatus is one of the most used concepts in the Ethics. In short, the two concepts seem to possess a high level of similarity without any explicit connections between them.

\section{Against the idea of an identity between the two principles}

Some great Spinoza scholars have proposed a quite interesting solution to the problem of the relation between these two principles. Amongst them, we can mention Jonathan Bennett, ${ }^{2}$ John Carriero ${ }^{3}$ and Lee C. Rice. ${ }^{4}$ As Valtteri Viljanen rightly says: for them, "the notion of conatus refers to a certain kind of metaphysical inertia through which finite things act, but by this nothing more is meant than that there is an attribute-neutral tendency in things to remain as they are." This inertial reading can be summarized in saying that, in the same way that the inertia prevents a body to modify its state of motion by itself, the conatus prevents a singular thing to modify its being by itself. In this reading, the two principles are understood as one.

Despite its consistency, I would like to argue that this reading is mainly wrong. The problem is that this reading seems to be based on the idea that E3P6

2 J. Bennett, A Study of Spinoza's Ethics, Indianapolis: Hackett Publishing Company, 1984; J. Bennett, "Teleology and Spinoza's Conatus," Midwest Studies in Philosophy 8, no. 1, 1983, 143-160.

3 J. Carriero, "Conatus and Perfection in Spinoza," Midwest Studies in Philosophy 35, no. 1, 2011, 69-92.

${ }^{4}$ L. C. Rice, "Emotion, Appetition, and Conatus in Spinoza," Revue Internationale de Philosophie 31, no. 1, 1977, 101-116.

5 V. Viljanen, Spinoza's Geometry of Power, Cambridge: Cambridge University Press, 2012, 107. 
is deduced solely by E3P4 and E3P5. The two propositions read as follows: "No thing can be destroyed except through an external cause" (E3P4); and "Things are of a contrary nature, that is, cannot be in the same subject, insofar as one can destroy the other" (E3P5). Were only of these two propositions, we could certainly say that the inertial reading is right.

But we must absolutely notice that there are, in fact, two lines of argumentation in the demonstration of E3P6. The inertial reading correctly places the emphasis on the idea that a thing cannot destroy itself, an idea which is confirmed by the formula as far as it can by its own. This idea is proven by the chain of argumentation that goes from E3P4 and E3P5 to E3P6. But the inertial reading does not put enough emphasis, if any at all (like in the case of Bennett), on the idea of power. Yet, this idea of power is probably the most important characteristic of the conatus, and it is introduced by E1P25C and E1P34 before the idea of the impossibility of auto-destruction. These two propositions, which are central to the Ethics, discuss the infinite power of God (E1P34) and about the part of that power that each singular thing expresses (E1P25C). I take the reference to these two propositions as essential to the correct understanding of the core of the concept of conatus. Now, it is clear that the idea of power seems to be totally absent from the concept of inertia, suggesting a profound difference between the two concepts.

However, in the Principia, the link between what we can consider as the ancestor of the conatus and the principle of inertia is clear: the principle of inertia is directly deduced from the conatus, since it is added as a corollary to the proposition introducing it. The question is why would Spinoza, who directly deduced the principle of inertia from the conatus in the Principia, not do the same in the Ethics?

In fact, I think that this problem is quickly resolved when we examine the evolution of the concept of conatus between the Principia and the Ethics. To fully see this evolution, it is important to read the Latin version of these texts. In the Principia, the philosopher states that "Unaquaeque res, quatenus simple et indivisa est, et in se sole consideratur, quantum in se est, semper in eodem statu perseverat" (PPC2P14). In the Ethics, though, Spinoza slightly changes the definition: "Unaquaeque res, quantum in se est, in suo esse perseverare conatur" (E3P6). At first sight, we can see that the two definitions are similar in various ways: (1) these two definitions apply to the same object: "unaquaeque res," which means all singular things; (2) we must notice the presence of the same formula i.e. "quantum in se est"; (3) and most importantly, these 
two definitions clearly describe something that we must define as a principle of conservation.

But, besides these similarities, there is one very important difference between the two versions of the definition. Rather than using the formula perseverare conatur as he will do in the Ethics, in the Principia, Spinoza only uses the verb perseverare without adding conatur. I take it to be of the first importance that the definition of what many commentators ${ }^{6}$ rightly consider as the ancestor of the conatus, does not even include the word conatus.

As Alexandre Matheron rightly mentions, and as it should now be clear, there is a notable evolution of the meaning of the conatus theory in the philosophy of Spinoza between the Principia and the Ethics. In the Short Treatise, Matheron says, "Spinoza talks about the striving of each thing to persevere in its state and to reach a better state: a static formulation and a dynamic one are

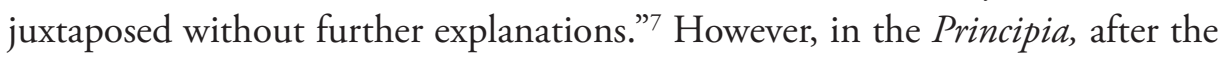
Short Treatise, there is only a static definition. Then, according to Matheron, the Ethics gives a dynamic meaning to the conatus and a strictly static meaning to the principle of inertia.

Even if Matheron is basically right, I think that we can clarify a little bit what he is saying. There are two major differences between the definition of the Ethics and the preceding definitions: (1) the use of the word 'state' or 'being'; (2) the presence or not of the word conatus. I will address these two major differences in detail since they are of the upmost importance for my purpose.

Before the Ethics, it seems that Spinoza almost exclusively used the word state $^{8}$ to talk about the conatus. Such is obviously the case in the Principia, and it also is in the TTP. On the contrary, in the Cogitata metaphysica, the philosopher uses the words "state" and "being" indifferently, as if there was no difference between the state and the being of a thing. Therefore, it must seem difficult to sustain that the use of the word being in the Ethics is of some importance.

${ }^{6}$ Just to name one amongst many: M. Della Rocca, "Spinoza’s Metaphysical Psychology," in: The Cambridge Companion to Spinoza, ed. D. Garrett, Cambridge: Cambridge University Press, 1996, 196. Even though Spinoza does not use the word conatus in it, I still think that the definition of the Principa is the ancestor of the definition of the conatus of the Ethics. Alexandre Matheron also thinks the same.

7 A. Matheron, "Le Problème de L'évolution de Spinoza Du Traité Théologico-Politique Au Traité Politique," in: Spinoza: Issues and Directions, ed. E. Curley et P.-F. Moreau (Leiden: Brill, 1990), 268.

8 The state of a body is nothing else than the set of physical properties of a body and all the relations this body entertains with other bodies. 
But I still think that the word being is quite important, in the Ethics at least. The fact is that between the state of a thing and its being, there is a huge difference, difference that Spinoza must have somehow finally noticed when he was writing the Ethics. This difference is much clearer in the original version of the text. Spinoza says that: "Unaquaeque res quantum in se est, in suo esse perseverare conatur". Here, a better translation for the word esse is probably existence rather than being. I think that it is what Spinoza tried to say and nothing else.

I think that the difference between the state and the being of a thing is significant with respect to the difference between the conatus and the principle of inertia. But for seeing why, we must first talk about the second major difference in the conatus theory of the Ethics. This difference is quite obvious and of a much greater importance than the first one. Indeed, there is a very strong difference between the fact that a thing perseveres in its state or in its being, and the fact that a thing strives to persevere in its state or in its being. In fact, we can easily see that the presence or the absence of the word conatus determines if the principle is dynamic or not. In the Ethics, I take it to be absolutely evident that the conatus is a dynamic principle. ${ }^{9}$ As we already highlighted it, the very fact that the demonstration of the conatus points toward the concept of power seems to be a strong enough argument to understand the conatus as a dynamic principle.

Now, what about the principle of inertia? Is it, as according to Matheron, a static principle? This claim seems to be plainly true. Once again, there is strong textual evidence to sustain this interpretation. The demonstration of the principle of inertia points toward the radical determinism and not directly toward the concept of power like the definition of the conatus does. The demonstration refers to E1P28. If we read the definition of the principle of inertia and E1P28, we can easily see that Spinoza basically gives a physical meaning to a metaphysic principle:

Proposition 28, Part 1: "Every singular thing, or any thing which is finite and has a determinate existence, can neither exist nor be determined to produce an effect unless it is determined to exist and produce an effect by another cause, which is also finite and has a determinate existence; and again, this cause also can neither exist

9 For a very good introduction to a reading of the conatus that correctly puts the emphasis on the concept of power, see V. Viljanen, "The meaning of the conatus doctrine," in: Spinoza's Geometry of Power, Cambridge: Cambridge University Press, 2012), 105-144, in: particular 125-144. See also G. Deleuze, Spinoza et le Problème de L'expression, Paris: Éditions de Minuit, 1968. 
nor be determined to produce an effect unless it is determined to exist and produce an effect by another, which is also finite and has a determinate existence, and so on, to infinity".

Lemma 3: "A body which moves or is at rest must be determined to motion or rest by another body, which has also been determined to motion or rest by another, and that again by another, and so on, to infinity".

\section{The shortcoming a concept}

In light of all of this, it might be useful to summarize the major arguments in favour of my thesis. Firstly, we saw that there are in the Ethics two principles of conservation and that these two principles are not explicitly linked together. We also saw that in the Principia these two concepts were linked, which forces us to explain why it is the case in the Principia but not in the Ethics. We then stated that there is a clear evolution on the meaning of the conatus in the philosophy of Spinoza: in the Ethics, the conatus is a dynamic principle that expresses a part of the infinite power of God, whereas the principle of inertia is a static principle.

But, to be absolutely clear, it may also be useful to explain what I mean by a static principle. If I call the principle of inertia a static principle, it is because the phenomenon which is described by the lemma 3 of the Ethics is exclusively deterministic. In other words, we know that from a given state of motion and rest will necessarily follow another determined state of motion and rest. A dynamic principle is a much more flexible principle. In respect to a dynamic principle, when an individual is confronted to a given state of affairs, this individual will act in some determined ways (ways and not way: the plural is very important).

This thesis is confirmed by the way in which each definition is written and used. On the first hand, in the case of the principle of inertia, a change in the state of a given body is clearly coming exclusively from outside of that body. By this I mean that the cause of the change in the state of a body cannot come from the inside of that body. On the other hand, according to the conatus theory, "each thing, as far as it can by its own power, strives to persevere in its being" (E3P6). Unlike the definition of the principle of inertia, we can see that the conatus theory supports the idea of a striving to act and that this striving comes from the inside of a given thing and not from the outside of it. This displacement of the cause from the outside to the inside was necessary: the theory of the affects of Spinoza needed 
it. Indeed, because it is based upon that idea of a striving that "pushes" from the inside of the thing. Here, we can see the importance of the concept of power. An affect appears when the outside and the inside are confronted with one another, when the power is aided or restrained. The principle of inertia was absolutely unfit for that purpose because when a body "expresses" its inertia, it does not really act. The inertia is just a property of a body and there is nothing that "pushes" inside that body: something reacts but nothing acts. It also explains why it is only in the Ethics that the conatus and the inertia are really distinguished: it is only in the Ethics that Spinoza wants to construct a theory of the affects.

I must absolutely answer a possible objection to this distinction. I am not saying that the theory of the affects of Spinoza is not mechanistic. Yet, when Spinoza wants to talk about the affects, even if he wants to do it in a mechanistic way, he still uses psychological laws instead of physical laws. My point is only to say that between the physical digression and the third part of the Ethics, Spinoza chose to use another point of view. From a static point of view, he switched to a dynamic point of view.

The point in this paper was not to say that there is no link between the principle of inertia and the conatus. I wanted to stress that given the radical determinism of Spinoza, these two points of view are only two different kinds of explanations. In my view, Spinoza preferred switching his point of view in the third part of the Ethics because the conatus, as a dynamic principle, is much more useful when comes the time of talking about the affects. In addition, both demonstrations of the conatus and of the principle of inertia point towards the same set of propositions, namely E1P15 and E1P25, though not in the same way. The radical determinism, which is described by these two propositions, is somehow at the roots of the two principles. Hence, the link between the concepts of conatus and inertia exists, but it is an indirect one.

\section{References}

Bennet, J., A Study of Spinoza's Ethics, Indianapolis: Hackett Publishing Company, 1984.

Bennet, J., "Teleology and Spinoza’s Conatus," Midwest Studies in Philosophy 8.1, 1983, $143-160$.

Carriero, J., "Conatus and Perfection in Spinoza," Midwest Studies in Philosophy 35.1, 2011, 69-92.

Curley, E., A Spinoza Reader: The Ethics and Other Works, Princeton: Princeton University Press, 1994. 
Deleuze, G., Spinoza et le Problème de L'expression, Paris: Éditions de Minuit, 1968.

Della Rocca, M., "Spinoza's Metaphysical Psychology," in: The Cambridge Companion to Spinoza, ed. D. Garrett, Cambridge: Cambridge University Press, 1996.

Matheron, A., "Le Problème de L'évolution de Spinoza Du Traité Théologico-Politique Au Traité Politique," Spinoza: Issues and Directions, E. Curley, P.-F. Moreau (eds.), Leiden: Brill, 1990.

Rice, L. C., "Emotion, Appetition, and Conatus in Spinoza," Revue Internationale de Philosophie 31.1 (1977): 101-116.

Viljanen, V., Spinoza’s Geometry of Power, Cambridge: Cambridge University Press, 2012. 